\title{
Effects of Hydrothermal Time on Structure and Photocatalytic Property of Titanium Dioxide for Degradation of Rhodamine B and Tetracycline Hydrochloride
}

\author{
Mao Tang ${ }^{1}$, Yangwen Xia ${ }^{1}$, Daixiong Yang ${ }^{1}$, Jiawei Liu ${ }^{1}$, Xiaodong Zhu ${ }^{1, * \mathbb{D}}$ and Renyong Tang ${ }^{2, *}$ \\ 1 School of Mechanical Engineering, Chengdu University, Chengdu 610106, China; tangmao@cdu.edu.cn (M.T.); \\ x1278704108@163.com (Y.X.); yangdaixiong1998@163.com (D.Y.); jiawei081999@163.com (J.L.) \\ 2 School of Food and Biological Engineering, Chengdu University, Chengdu 610106, China \\ * Correspondence: xiaodangjia21@126.com (X.Z.); tangrenyong@cdu.edu.cn (R.T.)
}

check for

updates

Citation: Tang, M.; Xia, Y.; Yang, D.; Liu, J.; Zhu, X.; Tang, R. Effects of Hydrothermal Time on Structure and Photocatalytic Property of Titanium Dioxide for Degradation of Rhodamine B and Tetracycline Hydrochloride. Materials 2021, 14, 5674. https://doi.org/10.3390/ ma14195674

Academic Editor: Zoltán Erdélyi

Received: 7 August 2021

Accepted: 26 September 2021

Published: 29 September 2021

Publisher's Note: MDPI stays neutral with regard to jurisdictional claims in published maps and institutional affiliations.

Copyright: (c) 2021 by the authors. Licensee MDPI, Basel, Switzerland. This article is an open access article distributed under the terms and conditions of the Creative Commons Attribution (CC BY) license (https:/ / creativecommons.org/licenses/by/ $4.0 /)$.

\begin{abstract}
Using butyl titanate and absolute ethanol as raw materials, $\mathrm{TiO}_{2}$ was prepared by a hydrothermal method with different hydrothermal times, and the influences of hydrothermal time on the structure and photocatalytic performance of $\mathrm{TiO}_{2}$ were investigated. The obtained samples were characterized by XRD, SEM, TEM, BET, PL and DRS, separately. The results show that $\mathrm{TiO}_{2}$ forms anatase when the hydrothermal time is $12 \mathrm{~h}$, forms a mixed crystal composed of anatase and rutile when the hydrothermal time is $24 \mathrm{~h}$, and forms rutile when the hydrothermal time is $36 \mathrm{~h}$. With the extension of hydrothermal time, anatase gradually transforms into rutile and the surface area decreases. Although $\mathrm{TiO}_{2}-24 \mathrm{~h}$ and $\mathrm{TiO}_{2}-36 \mathrm{~h}$ show lower photoinduced charge recombination and higher light source utilization, $\mathrm{TiO}_{2}-12 \mathrm{~h}$ exhibits the highest photocatalytic activity owing to its largest surface area $\left(145.3 \mathrm{~m}^{2} / \mathrm{g}\right)$. The degradation degree of rhodamine B and tetracycline hydrochloride reach $99.6 \%$ and $90.0 \%$ after $45 \mathrm{~min}$.
\end{abstract}

Keywords: $\mathrm{TiO}_{2}$; hydrothermal time; surface area; photocatalytic activity

\section{Introduction}

Employing photocatalytic technology to degrade pollutants is an effective route for environmental governance. $\mathrm{TiO}_{2}$ has received extensive attention due to its advantages such as chemical stability, low cost, mild reaction conditions and high photocatalytic activity [1-5]. The crystal structure, crystallinity, surface morphology, specific surface area and optical property of $\mathrm{TiO}_{2}$ are closely related to the preparation method. The most commonly used methods are mainly sol-gel [6-8] and hydrothermal methods [9-12]. Zhu et al. [6] used sol-gel methods to synthesize $\mathrm{TiO}_{2}$ under calcination at $540{ }^{\circ} \mathrm{C}$. The particles are spherical with a certain extent agglomeration and the surface area is $40 \mathrm{~m}^{2} / \mathrm{g}$. It is convenient to control the morphology of photocatalyst by a hydrothermal method, which does not require high-temperature calcination and is conducive to obtaining a large surface area and high photocatalytic activity [13-18]. Esparza et al. [16] prepared nanostructured $\mathrm{TiO}_{2}$ by a hydrothermal method. The crystal grain size was $13 \mathrm{~nm}$, and the particles were composed of nanotubes and nanosheets with a large surface area $\left(269 \mathrm{~m}^{2} / \mathrm{g}\right)$. Methylene blue (MB) was completely degraded under UV light after $120 \mathrm{~min}$. Zhu et al. [13] prepared $\mathrm{Cu}$-doped $\mathrm{TiO}_{2}$ under the conditions of $20{ }^{\circ} \mathrm{C}$ for $12 \mathrm{~h}$ by hydrothermal method. It was found that the photocatalyst was anatase/rutile mixed crystal structure and the surface area was $73.9 \mathrm{~m}^{2} / \mathrm{g}$. The decolorization degree of rhodamine (RhB) was $99.4 \%$ after 60 min. Nesic et al. [18]. prepared lanthanum and vanadium co-doped titanium dioxide by a microwave-assisted hydrothermal method. The samples showed high crystallinity and were all anatase structures. The specific surface area of $0.02 \mathrm{~V}-2 \mathrm{La} / \mathrm{TiO}_{2}$ was $125 \mathrm{~m}^{2} / \mathrm{g}$, and the decolorization degree of $\mathrm{RhB}$ was more than $90 \%$ after $90 \mathrm{~min}$.

Hydrothermal conditions will affect the crystal structure, surface morphology and specific surface area, thereby affecting the photocatalytic performance [19,20]. Lee et al. [19] 
studied the effects of hydrothermal temperature from 120 to $210^{\circ} \mathrm{C}$ on the morphology and photocatalytic performance of $\mathrm{TiO}_{2}$. The results show that the particles gradually change from granular to nanotube with the increasing temperature and $\mathrm{TiO}_{2}$ prepared at $180{ }^{\circ} \mathrm{C}$ displays the best photocatalytic performance. Changing the ratio of reactants can also affect the structure and photocatalytic performance of the products [21,22]. Li et al. [21] prepared $\mathrm{TiO}_{2}$ by using different molar ratios of tartaric acid to $\mathrm{TiCl}_{3}$. When the tartaric acid: $\mathrm{TiCl}_{3}$ is 0.1 , the photocatalytic activity is the highest.

In the present study, at the fixed hydrothermal temperature $200^{\circ} \mathrm{C}, \mathrm{TiO}_{2}$ photocatalysts were prepared with a hydrothermal time of 12,24 and $36 \mathrm{~h}$, respectively. The obtained samples were characterized by XRD, SEM, TEM, BET, PL, DRS and the degradation of $\mathrm{RhB}$ and tetracycline hydrochloride (TC) to study the effects of hydrothermal time on the crystal structure, morphology, specific surface area, optical property and photocatalytic performance of $\mathrm{TiO}_{2}$.

\section{Experimental Section}

\subsection{Material Preparation}

$10 \mathrm{~mL}$ butyl titanate and $20 \mathrm{~mL}$ absolute ethanol were mixed to prepare solution A. Solution B was made of $30 \mathrm{~mL}$ deionized water, $2 \mathrm{~mL}$ hydrochloric acid and $2 \mathrm{~mL}$ polyethylene glycol, which was added to solution A dropwise. After stirring for $1 \mathrm{~h}$, the mixture was transfer into a $100 \mathrm{~mL}$ hydrothermal reactor and kept at $200{ }^{\circ} \mathrm{C}$ for $12 \mathrm{~h}$, $24 \mathrm{~h}$ and $36 \mathrm{~h}$. After washing and drying, $\mathrm{TiO}_{2}$ photocatalysts were obtained. No further calcination process was performed. The samples obtained with different hydrothermal times were labeled as $\mathrm{TiO}_{2}-12 \mathrm{~h}, \mathrm{TiO}_{2}-24 \mathrm{~h}$ and $\mathrm{TiO}_{2}-36 \mathrm{~h}$.

\subsection{Characterization}

The crystal structure was characterized by DX-2700 X-ray diffractometer (XRD). Morphology was observed using Hitachi SU8220 scanning electron microscope (SEM) and FEI-Tecnai G2 F20 transmission electron microscope (TEM). Surface area was measured by an ASAP2460 surface area analyzer (BET). The optical property was studied using UV-3600 ultraviolet-visible spectrophotometer (DRS) and F-4600 fluorescence spectrometer (PL).

\subsection{Photocatalysis Experiment}

To achieve adsorption and desorption equilibrium, $0.1 \mathrm{~g} \mathrm{TiO}_{2}$ powder and $100 \mathrm{~mL}$ $(10 \mathrm{mg} / \mathrm{L}) \mathrm{RhB}$ solution or $100 \mathrm{~mL}(30 \mathrm{mg} / \mathrm{L}) \mathrm{TC}$ solution were mixed and then stirred $30 \mathrm{~min}$ in the dark. Using a $250 \mathrm{~W}$ xenon lamp as the light source, the mixture was taken every $15 \mathrm{~min}$ to measure the absorbance and the degradation degree was calculated by the formula $\left(\mathrm{A}_{0}-\mathrm{A}_{\mathrm{t}}\right) / \mathrm{A}_{0} \times 100 \%$.

\section{Results and Discussion}

\subsection{Crystal Structure}

Figure 1 exhibits the XRD patterns of samples. All peaks in $\mathrm{TiO}_{2}-12 \mathrm{~h}$ correspond to anatase structure, indicating $\mathrm{TiO}_{2}$ forms anatase when the hydrothermal time is $12 \mathrm{~h}$. The peak intensity of anatase (101) plane in $\mathrm{TiO}_{2}-24 \mathrm{~h}$ drops sharply, and the peaks of anatase (004), (200), (105), (204) planes disappear. Only the peaks around 25.3 and $48.1^{\circ}$ ascribing to the (101) and (200) crystal planes of anatase structure can be detected. Meanwhile, the rutile diffraction peaks appear and the intensity is much higher than anatase, implying that $\mathrm{TiO}_{2}-24 \mathrm{~h}$ forms anatase/rutile mixed crystal structure. The mass fraction of anatase $\left(\mathrm{X}_{\mathrm{A}}\right)$ can be calculated by the following formula [2,21]:

$$
\mathrm{X}_{\mathrm{A}}=\left(1+1.26\left(\mathrm{I}_{\mathrm{R}} / \mathrm{I}_{\mathrm{A}}\right)\right)^{-1}
$$

where $I_{A}$ and $I_{R}$ represent the intensities of anatase (101) plane and rutile (110) plane, respectively. The mass fraction of anatase phase is $7.1 \%$ and the mass fraction of rutile phase is $92.9 \%$ in $\mathrm{TiO}_{2}-24$ sample. The anatase diffraction peaks in $\mathrm{TiO}_{2}-36 \mathrm{~h}$ disappear wholly and all the peaks can be attributed to rutile, which indicates that the transformation 
from anatase to rutile has been completed when hydrothermal time is $36 \mathrm{~h}[23,24]$. The grain sizes (D) of samples were calculated by the Scherrer formula [2]:

$$
\mathrm{D}=0.89 \lambda / \beta \cos \theta
$$

where $\lambda$ represents the wavelength of $\mathrm{Cu} \mathrm{Ka}, \beta$ represents the full width at half maximum of the XRD peak ((101) plane for anatase and (110) plane for rutile), and $2 \theta$ represents the Bragg diffraction angle. The grain sizes (D) of $\mathrm{TiO}_{2}-12, \mathrm{TiO}_{2}-24$ and $\mathrm{TiO}_{2}-36$ are $9.9 \mathrm{~nm}$, $13.2 \mathrm{~nm}$ (anatase) $/ 35.0 \mathrm{~nm}$ (rutile) and $27.5 \mathrm{~nm}$.

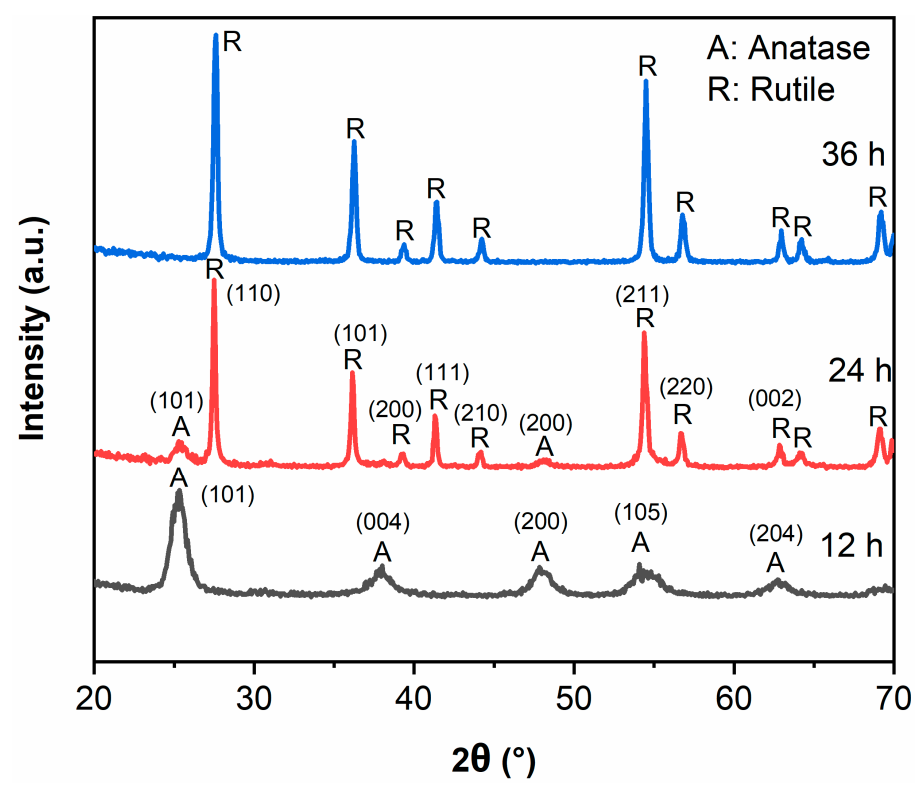

Figure 1. $\mathrm{XRD}$ patterns of $\mathrm{TiO}_{2}-12 \mathrm{~h}, \mathrm{TiO}_{2}-24 \mathrm{~h}$ and $\mathrm{TiO}_{2}-36 \mathrm{~h}$.

\subsection{Morphology and Surface Area}

Figure 2 depicts the SEM images of $\mathrm{TiO}_{2}-12 \mathrm{~h}, \mathrm{TiO}_{2}-24 \mathrm{~h}$ and $\mathrm{TiO}_{2}-36 \mathrm{~h}$. It is observed in Figure $2 \mathrm{a}$ that $\mathrm{TiO}_{2}-12 \mathrm{~h}$ is composed of fine particles which further constitute agglomerates. The agglomerate size ranges from tens to hundreds of nanometers. The agglomeration of $\mathrm{TiO}_{2}-24 \mathrm{~h}$ in Figure $2 \mathrm{~b}$ is more obvious. In Figure 2c, the particles of $\mathrm{TiO}_{2}-36 \mathrm{~h}$ are flaky and massive.
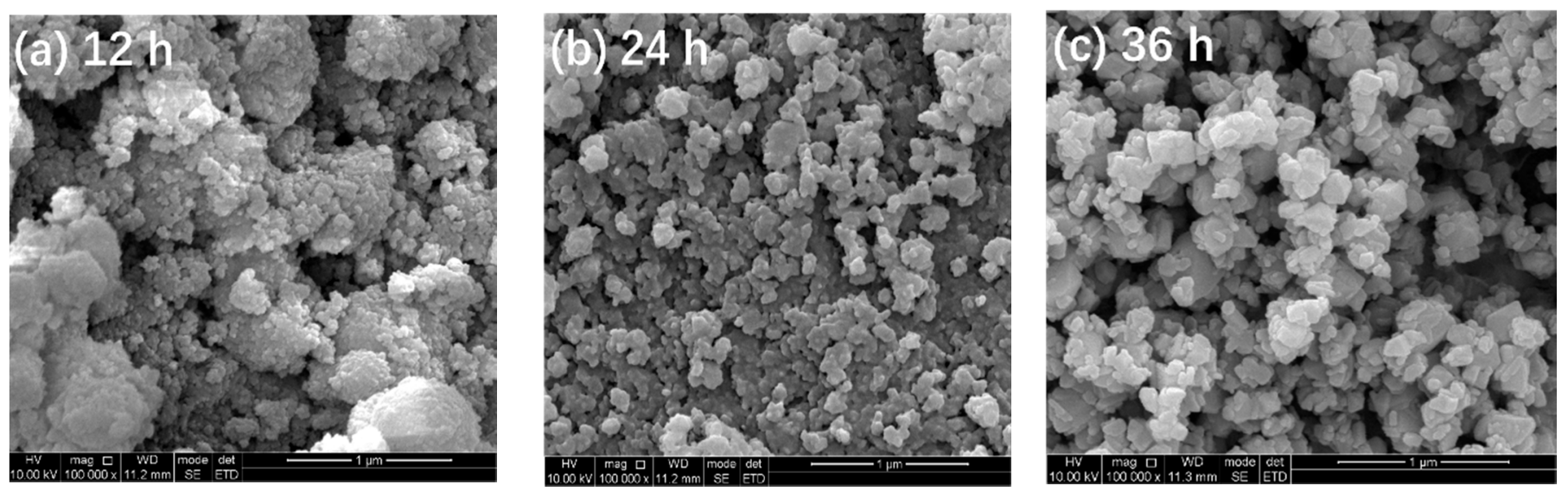

Figure 2. $\mathrm{SEM}$ images of $\mathrm{TiO}_{2}-12 \mathrm{~h}(\mathbf{a}), \mathrm{TiO}_{2}-24 \mathrm{~h}(\mathbf{b})$ and $\mathrm{TiO}_{2}-36 \mathrm{~h}$ (c).

Figure 3 presents the TEM and HRTEM images of $\mathrm{TiO}_{2}-12 \mathrm{~h}$ Figure $3 \mathrm{a}, \mathrm{b}, \mathrm{TiO}_{2}-24 \mathrm{~h}$ Figure $3 c, d$ and $\mathrm{TiO}_{2}-36 \mathrm{~h}$ Figure $3 \mathrm{e}, \mathrm{f}$. In Figure $3 \mathrm{a}$, the particles are relatively dispersed and the size of a single particle is around $10 \mathrm{~nm}$. The interplanar spacing in Figure $3 \mathrm{~b}$ is 
$0.351 \mathrm{~nm}$, corresponding to the (101) crystal plane of anatase [5]. It is observed from Figure $3 \mathrm{c}$ that the size of a single particle is $15-30 \mathrm{~nm}$, which is larger than that of $\mathrm{TiO}_{2}-12 \mathrm{~h}$. In addition to the granular shape, several particles exhibit rod and block shapes. The length of the nanorods is about $50 \mathrm{~nm}$ and the width is $15 \mathrm{~nm}$. The size of the blocks is $50-100 \mathrm{~nm}$. In Figure $3 \mathrm{~d}$, the marked interplanar spacing $0.348 \mathrm{~nm}$ corresponds to the (101) crystal plane of anatase and $0.320 \mathrm{~nm}$ corresponds to the (110) crystal plane of rutile [13,20], indicating that $\mathrm{TiO}_{2}-24 \mathrm{~h}$ is a mixed crystal composed of anatase and rutile, which is in line with XRD results. Nanoparticle almost disappears in Figure $3 \mathrm{e}$ and the particles are completely made of rods and blocks. The length of rods is $100 \mathrm{~nm}$ and the width is approximately $20 \mathrm{~nm}$. The size of the blocks is around $120 \mathrm{~nm}$. The interplanar spacing marked in Figure $3 \mathrm{f}$ is $0.322 \mathrm{~nm}$, corresponding to the (110) crystal plane of rutile.
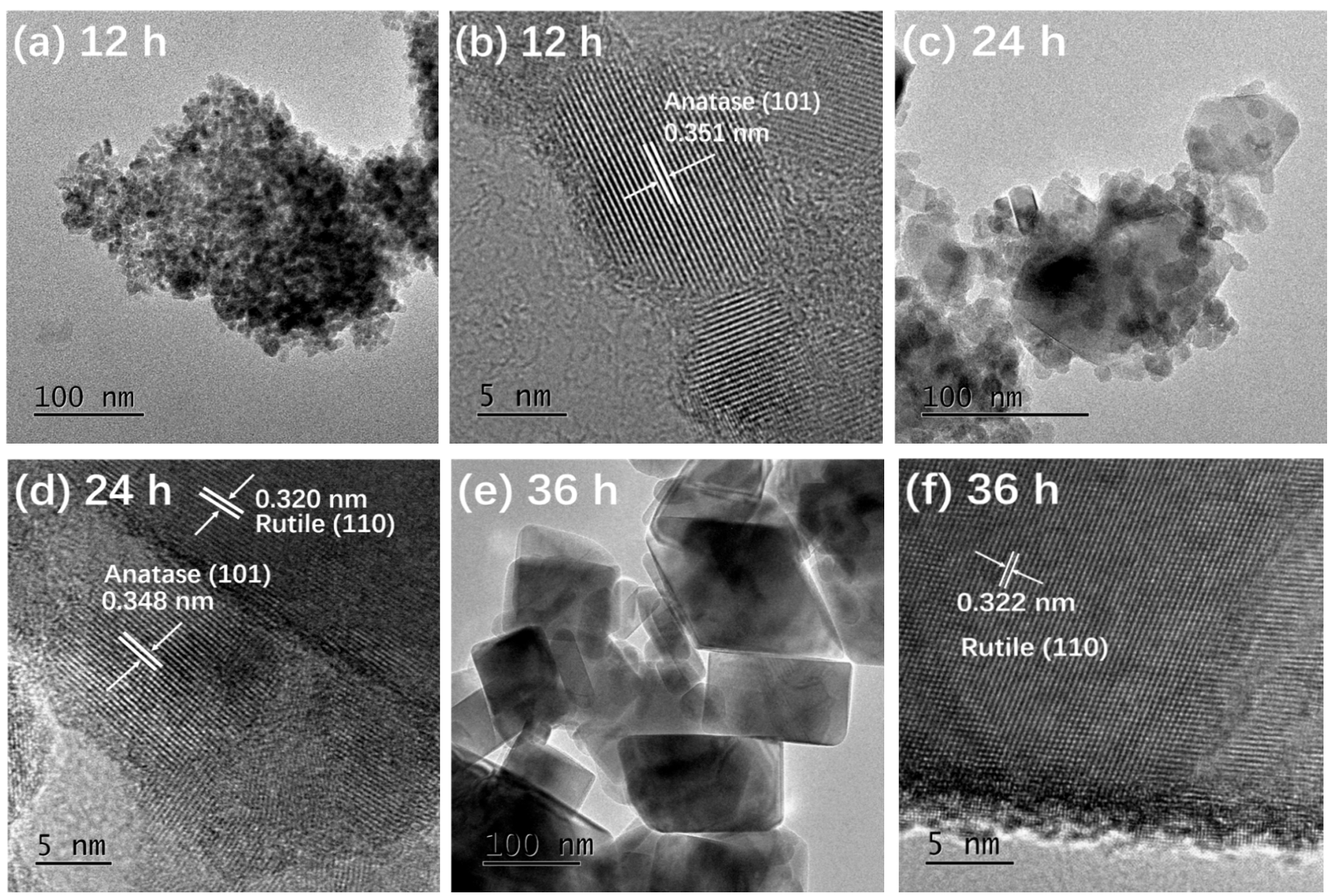

Figure 3. TEM and HRTEM images of $\mathrm{TiO}_{2}-12 \mathrm{~h}(\mathbf{a}, \mathbf{b}) \mathrm{TiO}_{2}-24 \mathrm{~h}(\mathbf{c}, \mathbf{d})$ and $\mathrm{TiO}_{2}-36 \mathrm{~h}(\mathbf{e}, \mathbf{f})$.

The morphology of $\mathrm{TiO}_{2}$ has a great impact on surface area and adsorption performance. It is found in Figure 3 that with the extension of hydrothermal time, the single particle size increases and the morphology changes significantly, which may lead to the surface area difference. To clarify the influences of hydrothermal time on surface area and the porosity of samples, the textural properties of samples have been implemented and the results are shown in Figure 4 and Table 1 . Both $\mathrm{TiO}_{2}-12 \mathrm{~h}$ and $\mathrm{TiO}_{2}-24 \mathrm{~h}$ are mesoporous materials. The pore size distribution curve of $\mathrm{TiO}_{2}-12 \mathrm{~h}$ shows a narrow peak, and its pore size distribution is uniform, and the pore size is between $5-15 \mathrm{~nm}$. The pore size distribution curve of $\mathrm{TiO}_{2}-24 \mathrm{~h}$ shows a broad peak shape, and the pore size distribution is uneven with a size of $5-50 \mathrm{~nm}$. There is no peak in the pore size distribution curve of $\mathrm{TiO}_{2}-36$ $\mathrm{h}$, indicating that no obvious mesopores can be detected in $\mathrm{TiO}_{2}-36 \mathrm{~h}$. The BET surface area, pore volume and average pore size of samples are summarized in Table 1. As the 
hydrothermal time increases, the BET surface area decreases from $145.3 \mathrm{~m}^{2} / \mathrm{g}$ to $43.0 \mathrm{~m}^{2} / \mathrm{g}$ and $13.3 \mathrm{~m}^{2} / \mathrm{g}$, and the pore volume is reduced from $0.264 \mathrm{~cm}^{3} / \mathrm{g}$ to $0.107 \mathrm{~cm}^{3} / \mathrm{g}$ and $0.029 \mathrm{~cm}^{3} / \mathrm{g}$. TEM images show that as hydrothermal time increases from 12 to $24 \mathrm{~h}$, part of fine nanoparticles aggregate to form nanorods and nanoblocks. When the reaction time is $36 \mathrm{~h}$, all the nanoparticles aggregate to form nanorods and nanoblocks. The agglomeration phenomenon is further intensified, and the BET surface area and pore volume are reduced.
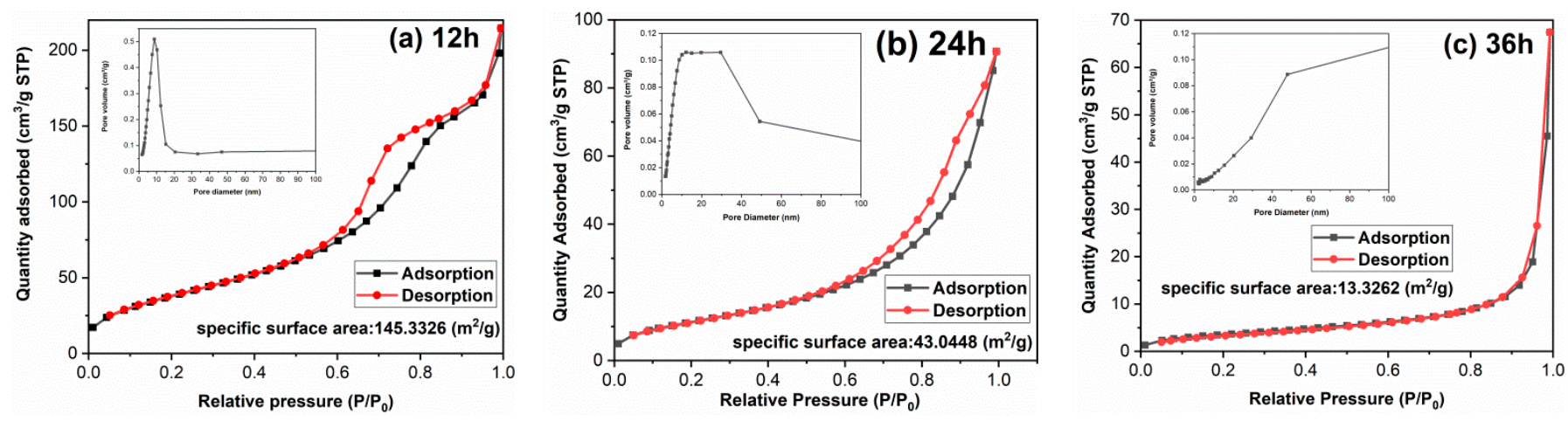

Figure 4. Nitrogen adsorption-desorption isotherms and pore size distribution curves of samples: (a) $\mathrm{TiO}_{2}-12 \mathrm{~h}$, (b) $\mathrm{TiO}_{2}-24 \mathrm{~h}$ and (c) $\mathrm{TiO}_{2}-36 \mathrm{~h}$.

Table 1. Textural properties of samples.

\begin{tabular}{cccc}
\hline Samples & BET Surface Area $\left(\mathbf{m}^{2} / \mathbf{g}\right)$ & Pore Volume $\left(\mathrm{cm}^{3} / \mathbf{g}\right)$ & Average Pore Size $(\mathbf{n m})$ \\
\hline $\mathrm{TiO}_{2}-12$ & 145.3 & 0.264 & 7.26 \\
$\mathrm{TiO}_{2}-24$ & 43.0 & 0.107 & 9.93 \\
$\mathrm{TiO}_{2}-36$ & 13.3 & 0.029 & 8.74 \\
\hline
\end{tabular}

Controlling the morphology of $\mathrm{TiO}_{2}$ and increasing its specific surface area is a research hotspot [25-27]. Du et al. [25] prepared porous Sn-doped $\mathrm{TiO}_{2}$ using polystyrene microspheres as a template. After calcination to remove the template, the porous structure was fabricated and the surface area reached $71.1 \mathrm{~m}^{2} / \mathrm{g}$. Huang et al. [26] used a sol-gel method combined with a hydrothermal method to prepare $\mathrm{TiO}_{2}$ microspheres by a two-step reaction. The diameter of the microspheres was about 200-500 $\mathrm{nm}$ and the surface area was $91.1 \mathrm{~m}^{2} / \mathrm{g}$. $\mathrm{TiO}_{2}$ nanospheres with diameter of $50-100 \mathrm{~nm}$ and surface area of $70.0 \mathrm{~m}^{2} / \mathrm{g}$ were fabricated by hydrothermal method in Mohamed et al.'s work [27]. In the present study, $\mathrm{TiO}_{2}-12 \mathrm{~h}$ exhibits a relatively large surface area $\left(145.3 \mathrm{~m}^{2} / \mathrm{g}\right)$, which may result in high photocatalytic activity.

\subsection{Optical Property}

Figure 5 shows the UV-visible absorption spectra of samples. The absorption edge of $\mathrm{TiO}_{2}-12 \mathrm{~h}$ is $387 \mathrm{~nm}[28,29]$, which corresponds to anatase structure. The absorption edges are 403 and $402 \mathrm{~nm}$ for $\mathrm{TiO}_{2}-24 \mathrm{~h}$ and $\mathrm{TiO}_{2}-36 \mathrm{~h}$, respectively. The band gap of rutile is smaller than anatase, thus $\mathrm{TiO}_{2}-24 \mathrm{~h}$ and $\mathrm{TiO}_{2}-36 \mathrm{~h}$, which mainly consist of rutile, show red shift compared to $\mathrm{TiO}_{2}-12 \mathrm{~h}$.

The PL peaks are derived from the recombination of photogenerated electrons and holes, thus the lower peak intensity and the lower recombination rate [30,31]. The PL spectra of samples are shown in Figure 6. It is generally believed that the recombination rate of anatase is lower than rutile [32,33], however, the PL peak intensity of $\mathrm{TiO}_{2}-12 \mathrm{~h}$ is the highest in the present work. XRD results show that the peak intensity of $\mathrm{TiO}_{2}-12 \mathrm{~h}$ is low and the half-height width of peak is large, indicating that $\mathrm{TiO}_{2}-12 \mathrm{~h}$ displays poor crystallinity with plentiful defects and oxygen vacancies. Photoinduced charges will be captured by defects and oxygen vacancies, which is in favor of retarding the recombination. However, excess defects or oxygen vacancies will introduce new recombination centers, enhancing the PL peak intensity [34]. With the increase in hydrothermal time, the crys- 
tallinity of the sample improves and the defects and oxygen vacancies reduce. Moderate defects and oxygen vacancies are beneficial to the separation of photogenerated electrons and holes $[35,36]$. Therefore, the PL peak intensity of $\mathrm{TiO}_{2}-24 \mathrm{~h}$ and $\mathrm{TiO}_{2}-36 \mathrm{~h}$ is lower than $\mathrm{TiO}_{2}-12$ h.

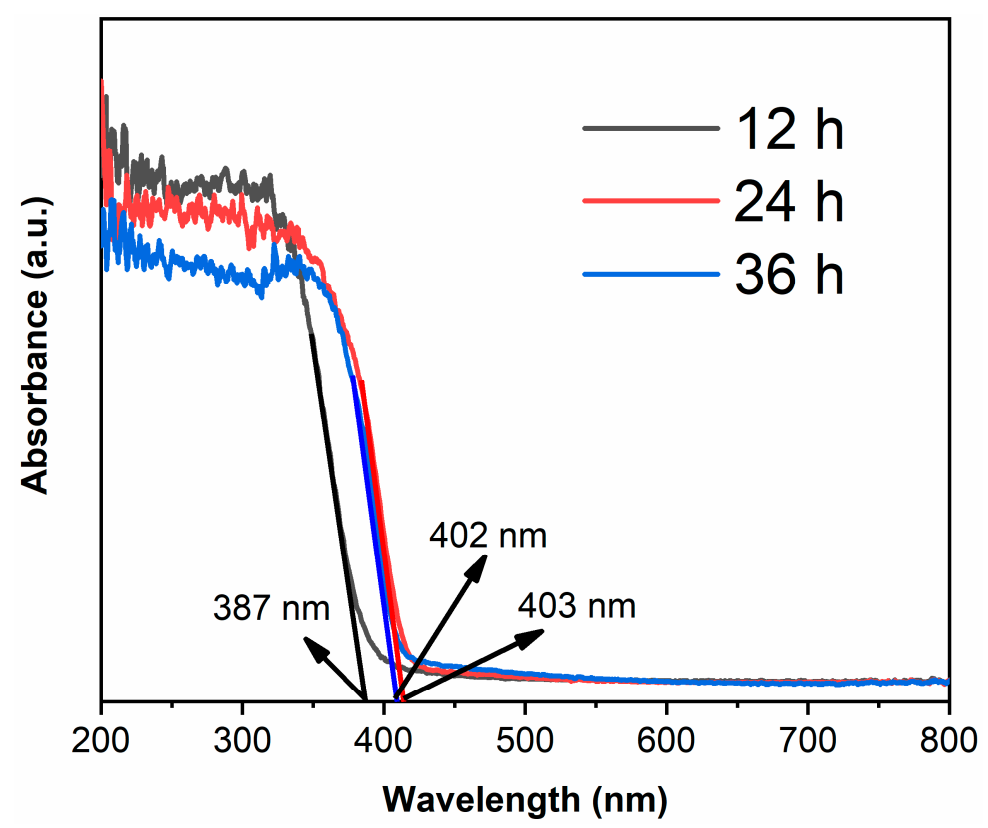

Figure 5. The UV-visible absorption spectra of $\mathrm{TiO}_{2}-12 \mathrm{~h}, \mathrm{TiO}_{2}-24 \mathrm{~h}$ and $\mathrm{TiO}_{2}-36 \mathrm{~h}$.

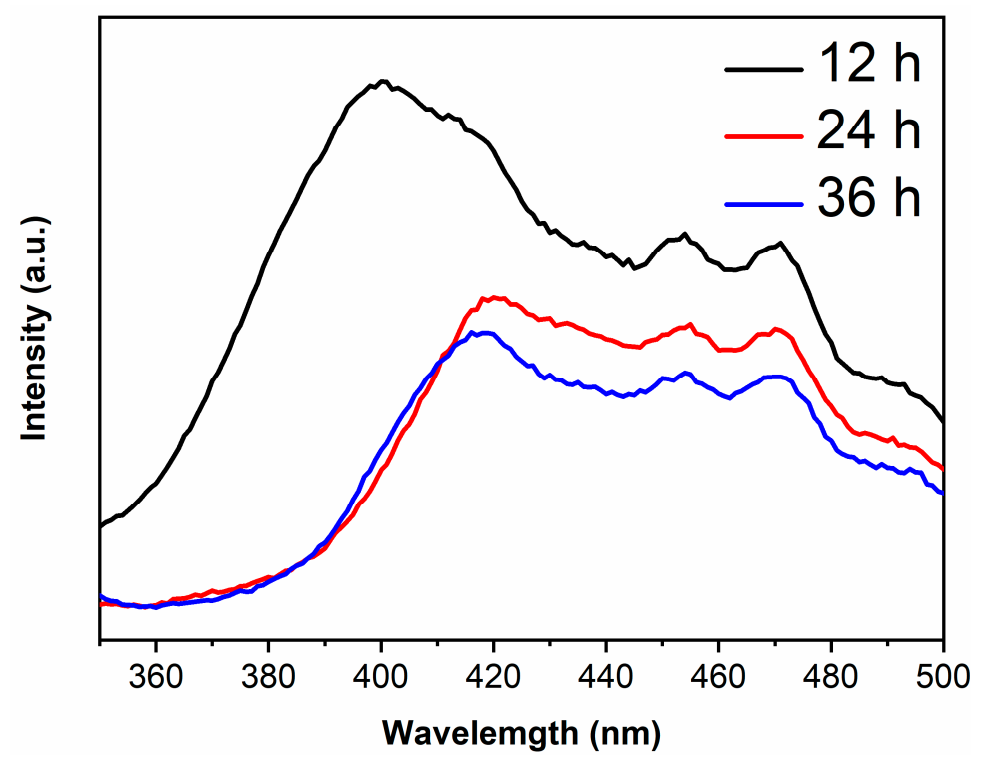

Figure 6. The PL spectra of $\mathrm{TiO}_{2}-12 \mathrm{~h}, \mathrm{TiO}_{2}-24 \mathrm{~h}$ and $\mathrm{TiO}_{2}-36 \mathrm{~h}$.

The PL main peak originates from photogenerated electrons in the conduction band returning directly to the valence band and recombining with holes, therefore, the wavelength corresponding to main peak in PL spectra is related to the band gap $[37,38]$. The main peak wavelengths of $\mathrm{TiO}_{2}-12 \mathrm{~h}, \mathrm{TiO}_{2}-24 \mathrm{~h}$ and $\mathrm{TiO}_{2}-36 \mathrm{~h}$ are 400, 415 and $415 \mathrm{~nm}$, which are right shifted about $13 \mathrm{~nm}$ compared to their absorption edges due to the Stokes shift $[39,40]$.

\subsection{Photocatalytic Activity}

Figure 7a shows the RhB decolorization curves of samples. Without catalyst, the decolorization degree of $\mathrm{RhB}$ is $2.6 \%$, which indicates that the decolorization of $\mathrm{RhB}$ is 
mainly due to the degradation of photocatalysts. The decolorization degrees of $\mathrm{TiO}_{2}-12 \mathrm{~h}$, $\mathrm{TiO}_{2}-24 \mathrm{~h}$ and $\mathrm{TiO}_{2}-36 \mathrm{~h}$ are 99.6, 46.3 and $81.8 \%$ after $45 \mathrm{~min}$. Figure $7 \mathrm{~b}$ displays the kinetics fitting curves of samples. The apparent first-order rate constants $\mathrm{k}$ of $\mathrm{TiO}_{2}-12 \mathrm{~h}, \mathrm{TiO}_{2}-24 \mathrm{~h}$ and $\mathrm{TiO}_{2}-36 \mathrm{~h}$ are $0.125,0.013$ and $0.024 \mathrm{~min}^{-1}$, respectively. $\mathrm{TiO}_{2}-12 \mathrm{~h}$ shows the highest photocatalytic activity. Although PL spectra and DRS spectra show that $\mathrm{TiO}_{2}-24 \mathrm{~h}$ and $\mathrm{TiO}_{2}-36 \mathrm{~h}$ exhibit a lower photogenerated charge recombination rate and higher visible light absorption, their photocatalytic activity is lower than that of $\mathrm{TiO}_{2}-12 \mathrm{~h}$ yet. Morphology and BET results show that $\mathrm{TiO}_{2}-12 \mathrm{~h}$ is composed of fine particles and possesses a relatively high surface area $\left(145.3 \mathrm{~m}^{2} / \mathrm{g}\right)$, which is much higher than $\mathrm{TiO}_{2}-24 \mathrm{~h}\left(43.0 \mathrm{~m}^{2} / \mathrm{g}\right)$ and $\mathrm{TiO}_{2}-36 \mathrm{~h}\left(13.3 \mathrm{~m}^{2} / \mathrm{g}\right)$. A high surface area provides more reactive sites, thus $\mathrm{TiO}_{2}-12 \mathrm{~h}$ shows the highest photocatalytic activity. Several $\mathrm{RhB}$ decolorization data reported by literatures via hydrothermal method are summarized in Table 2.
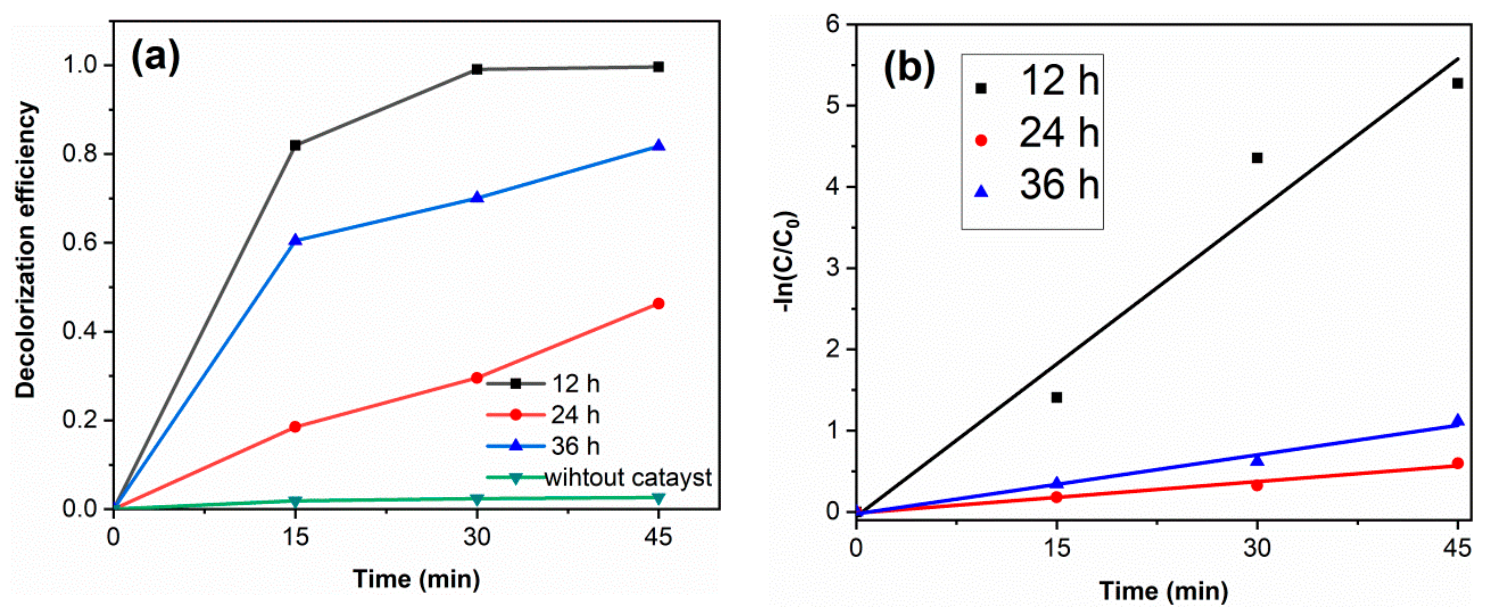

Figure 7. The RhB decolorization curves (a) and the kinetics fitting curves (b) of samples. (catalyst $0.1 \mathrm{~g}$, RhB solution $100 \mathrm{~mL}(10 \mathrm{mg} / \mathrm{L})$ and neutral $\mathrm{pH})$.

Table 2. The $\mathrm{RhB}$ decolorization data of $\mathrm{TiO}_{2}$ photocatalytic materials prepared by hydrothermal method.

\begin{tabular}{|c|c|c|c|c|c|}
\hline Refs & Method & Photocatalyst & Light Source & Decolorization Degree & $k\left(\min ^{-1}\right)$ \\
\hline [10] & hydrothermal method & $\mathrm{TiO}_{2}$ & Mercury lamp (500 W) & $96.0 \%$ in $90 \mathrm{~min}$ & - \\
\hline$[13]$ & hydrothermal method & $\mathrm{Cu}-\mathrm{TiO}_{2}$ & Xenon lamp $(250 \mathrm{~W})$ & $99.4 \%$ in $60 \mathrm{~min}$ & $0.076(\mathrm{RhB})$ \\
\hline [17] & hydrothermal method & $\mathrm{TiO}_{2}$ & Mercury lamp $(450 \mathrm{~W})$ & $92.0 \%$ in $30 \mathrm{~min}$ & $0.083(\mathrm{RhB})$ \\
\hline [41] & hydrothermal method & $\mathrm{Ag}-\mathrm{TiO}_{2}$ & Xenon lamp $(800 \mathrm{~W},>420 \mathrm{~nm})$ & $96.0 \%$ in $270 \mathrm{~min}$ & $0.011(\mathrm{RhB})$ \\
\hline [42] & hydrothermal method & $\mathrm{TiO}_{2}$ & Mercury lamp $(300 \mathrm{~W})$ & $58.0 \%$ in $15 \mathrm{~min}$ & $0.104(\mathrm{RhB})$ \\
\hline [43] & hydrothermal method & SDBS- $\mathrm{TiO}_{2}$ & Xenon lamp $(500 \mathrm{~W})$ & $90.0 \%$ in $120 \mathrm{~min}$ & $0.0185(\mathrm{RhB})$ \\
\hline [44] & hydrothermal method & $\mathrm{C}-\mathrm{TiO}_{2}$ & Xe lamp $(500 \mathrm{~W},>400 \mathrm{~nm})$ & $94.3 \%$ in $120 \mathrm{~min}$ & $0.022(\mathrm{RhB})$ \\
\hline [45] & hydrothermal method & $\mathrm{Ag}-\mathrm{TiO}_{2}$ & Xenon lamp $(500 \mathrm{~W})$ & $80.0 \%$ in $240 \mathrm{~min}$ & - \\
\hline [46] & hydrothermal method & $\mathrm{Ag}-\mathrm{TiO}_{2}$ & Xenon lamp (350 W) & $100 \%$ in $45 \mathrm{~min}$ & - \\
\hline [47] & hydrothermal method & $\mathrm{ZnO}-\mathrm{TiO}_{2}$ & Xenon lamp (350 W) & $85.5 \%$ in $60 \mathrm{~min}$ & $0.039(\mathrm{RhB})$ \\
\hline present work & hydrothermal method & $\mathrm{TiO}_{2}$ & Xenon lamp $(250 \mathrm{~W})$ & $99.0 \%$ in $30 \mathrm{~min}$ & $0.125(\mathrm{RhB})$ \\
\hline
\end{tabular}

To study the degradation effect of the prepared photocatalyst on pharmaceutical waste, tetracycline hydrochloride (TC) was selected as the target pollutant. The results are shown in Figure 8. The degradation degree of $\mathrm{TiO}_{2}-12 \mathrm{~h}, \mathrm{TiO}_{2}-24 \mathrm{~h}$ and $\mathrm{TiO}_{2}-36 \mathrm{~h}$ are $90.0,39.1$ and $62.4 \%$. The apparent first-order rate constants $\mathrm{k}$ of $\mathrm{TiO}_{2}-12 \mathrm{~h}, \mathrm{TiO}_{2}-24 \mathrm{~h}$ and $\mathrm{TiO}_{2}-36 \mathrm{~h}$ are $0.050,0.011$ and $0.022 \mathrm{~min}^{-1}$, respectively. The photodegradation results of $\mathrm{RhB}$ and TC confirm that $\mathrm{TiO}_{2}-12 \mathrm{~h}$ is an efficient photocatalyst, which shows potential application prospects in the field of dye wastewater and pharmaceutical wastewater. 

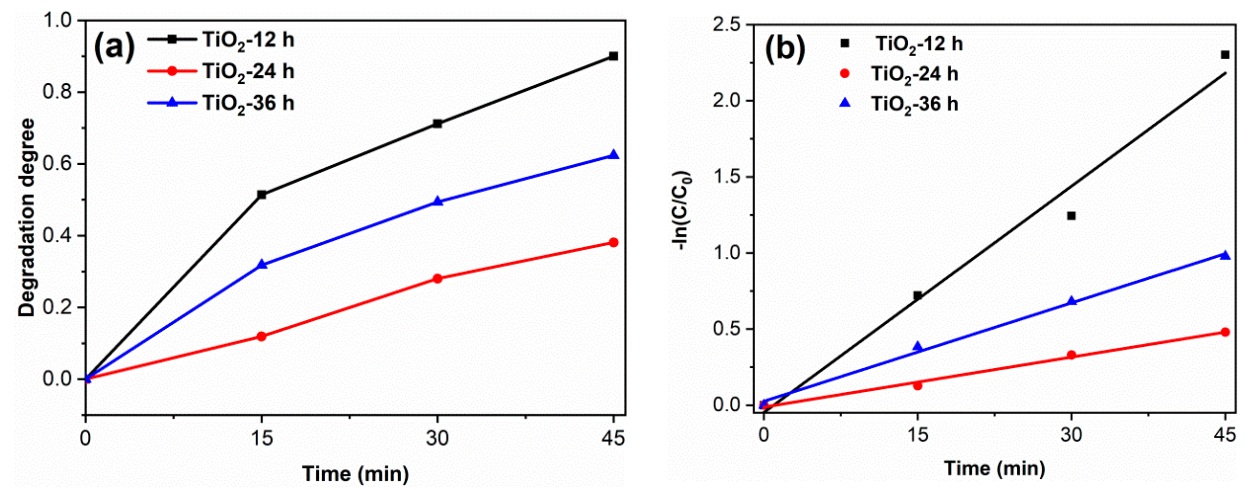

Figure 8. The TC degradation curves (a) and the kinetics fitting curves (b) of samples. (catalyst $0.1 \mathrm{~g}$, TC solution $100 \mathrm{~mL}(30 \mathrm{mg} / \mathrm{L})$ and neutral $\mathrm{pH})$.

\subsection{Photocatalytic Mechanism}

To verify the free radicals generated during the photocatalytic reaction, nitro-blue tetrazolium (NBT) and salicylic acid (SA) tests were carried out on $\mathrm{TiO}_{2}-12 \mathrm{~h}$ sample. The detailed processes of NBT and SA experiments are as follows: Add $0.1 \mathrm{~g} \mathrm{TiO}_{2}-12 \mathrm{~h}$ powder into $100 \mathrm{~mL} \mathrm{NBT}$ solution $(0.05 \mathrm{mmol} / \mathrm{L})$ and $100 \mathrm{~mL}$ SA solution $(0.02 \mathrm{~mol} / \mathrm{L})$, respectively, keep stirring, and test their absorbance every $15 \mathrm{~min}$ after light irradiation. The results are shown in Figure 9. The photoinduced electrons are excited to conduction band and react with $\mathrm{O}_{2}$ to produce $\mathrm{O}_{2}{ }^{-}$radicals, which further react with NBT. SA react with $\cdot \mathrm{OH}$ radicals, forming 2,3-HBA. Therefore, the decrease in NBT absorbance and the increased 2,3-HBA absorbance suggest that $\mathrm{O}_{2}{ }^{-}$and $\cdot \mathrm{OH}$ radicals are generated under irradiation [48,49].
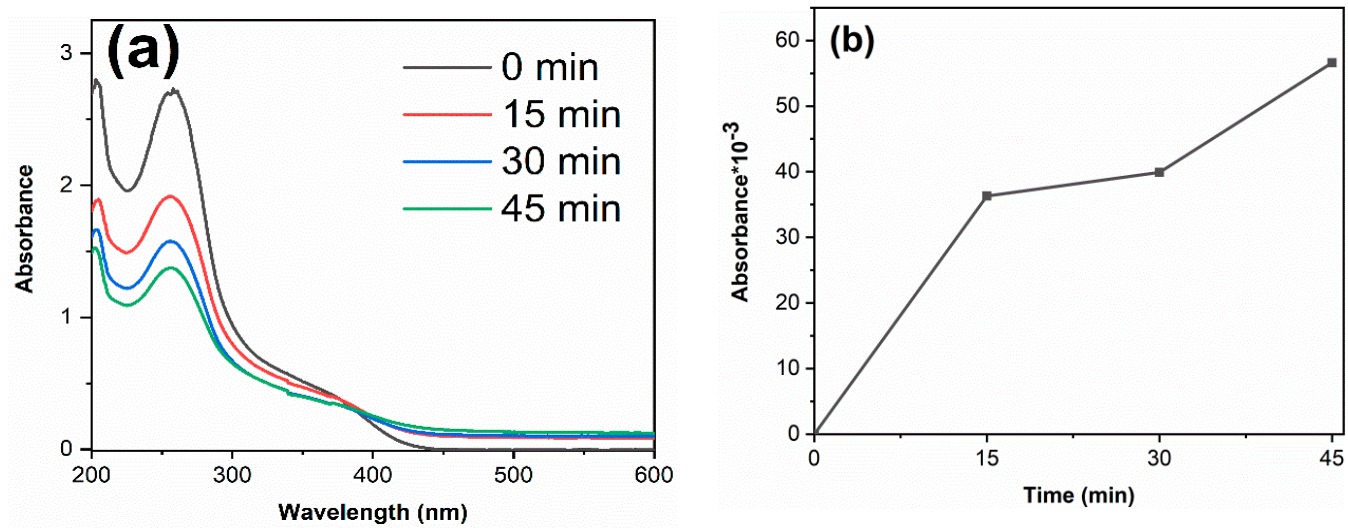

Figure 9. The absorbance curves of NBT (a) and 2, 3- $\mathrm{HBA}(\mathbf{b})$ of $\mathrm{TiO}_{2}-12 \mathrm{~h}$.

The active species in photocatalytic reaction process were investigated through adding benzoquinone (BQ), ammonium oxalate (AO) and isopropanol (IPA) as scavengers. The detailed processes of active species experiments are as follows: in the photocatalytic experiment, $2 \mathrm{~mL}(0.1 \mathrm{~mol} / \mathrm{L}) \mathrm{BQ}, \mathrm{AO}$ and IPA solutions were added, respectively, keeping other test conditions unchanged. The results are shown in Figure 10. The decolorization degree of $\mathrm{RhB}$ for $\mathrm{TiO}_{2}-12 \mathrm{~h}$ declines from 99.6 to $58.8,93.6$ and $94.0 \%$ in the presence of $\mathrm{BQ}$, $\mathrm{AO}$ and IPA, respectively. Meanwhile, The degradation degree of $\mathrm{TC}$ for $\mathrm{TiO}_{2}-12 \mathrm{~h}$ declines from 90.0 to $46.5,83.4$ and $80.3 \%$ in the presence of $B Q, A O$ and IPA. Since BQ, AO and IPA capture $\cdot \mathrm{O}_{2}{ }^{-}, \mathrm{h}^{+}$and $\mathrm{OH}$ species, it can be concluded that $\mathrm{O}_{2}{ }^{-}$radicals are the main active groups in the degradation process, and $\mathrm{h}^{+}$and $\mathrm{OH}$ radicals play a secondary role. 

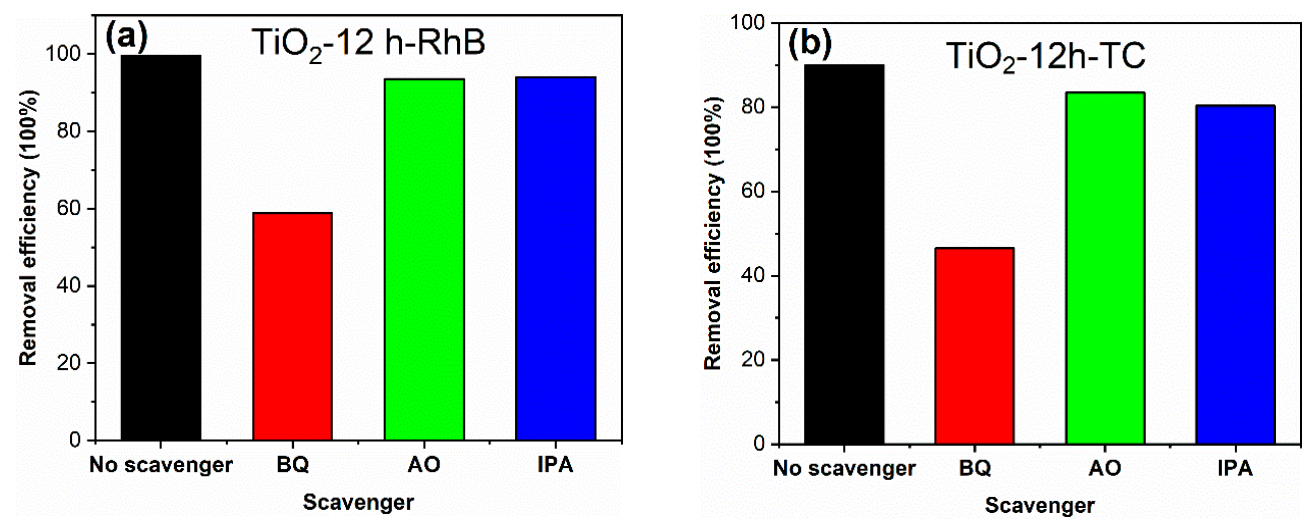

Figure 10. The degradation degrees of $\mathrm{TiO}_{2}-12 \mathrm{~h}$ towards $\mathrm{RhB}(\mathbf{a})$ and $\mathrm{TC}(\mathbf{b})$ in the presence of different scavengers.

\section{Conclusions}

In summary, the influences of hydrothermal time on the structure and photocatalytic performance of $\mathrm{TiO}_{2}$ were studied systematically. $\mathrm{TiO}_{2}-12 \mathrm{~h}$ forms anatase, $\mathrm{TiO}_{2}-24 \mathrm{~h}$ forms anatase/rutile mixed crystal, and $\mathrm{TiO}_{2}-36 \mathrm{~h}$ forms rutile. As the hydrothermal time increases, $\mathrm{TiO}_{2}$ gradually transforms from fine particles to lumps and the surface area decreases. $\mathrm{TiO}_{2}-24 \mathrm{~h}$ and $\mathrm{TiO}_{2}-36 \mathrm{~h}$ show a lower photogenerated charge recombination rate and higher visible light absorption, however, their photocatalytic activities are lower than that of $\mathrm{TiO}_{2}-12 \mathrm{~h}$, which can be attributed to the relatively high surface area $\left(145.3 \mathrm{~m}^{2} / \mathrm{g}\right)$ of $\mathrm{TiO}_{2}-12 \mathrm{~h}$. Active species tests confirm that $\mathrm{O}_{2}{ }^{-}$radicals are the main active groups in the degradation process.

Author Contributions: Design, M.T. and X.Z.; Experiment, Y.X., D.Y. and J.L.; Writing, M.T. and X.Z.; Supervision, X.Z. and R.T. All authors have read and agreed to the published version of the manuscript.

Funding: This research was funded by the Training Program for Innovation of Chengdu University grant number: CDU-CX-2021527 and S202011079053.

Informed Consent Statement: Not applicable.

Data Availability Statement: Data is contained within the article.

Conflicts of Interest: There are no conflict to declare.

\section{References}

1. Chen, Y.; Xiang, Z.; Wang, D.; Kang, J.; Qi, H. Effective photocatalytic degradation and physical adsorption of methylene blue using cellulose/GO/ $\mathrm{TiO}_{2}$ hydrogels. RSC Adv. 2020, 10, 23936-23943. [CrossRef]

2. Sun, Y.; Liu, E.D.; Zhu, L.; Wen, Y.; Tan, Q.W.; Feng, W. Influence of annealing temperature of $\mathrm{TiO}_{2}$ nanotubes via hydrothermal method on Ti foll for photocatalytic degradation. Dig. J. Nanomater. Bios. 2019, 14, 463-470.

3. Lin, X.; Rong, F; Fu, D.; Yuan, C. Enhanced photocatalytic activity of fluorine doped $\mathrm{TiO}_{2}$ by loaded with $\mathrm{Ag}$ for degradation of organic pollutants. Powder Technol. 2012, 219, 173-178. [CrossRef]

4. Li, X.; Xiong, J.; Huang, J.; Feng, Z.; Luo, J. Novel g- $\mathrm{C}_{3} \mathrm{~N}_{4} / \mathrm{h}^{\prime} \mathrm{ZnTiO}_{3}-\mathrm{a}^{\prime} \mathrm{TiO}_{2}$ direct Z-scheme heterojunction with significantly enhanced visible-light photocatalytic activity. J. Alloys Compd. 2019, 774, 768-778. [CrossRef]

5. Chen, J.F.; Zhang, X.D.; Shi, X.Y.; Bi, F.K.; Yang, Y.; Wang, Y.X. Synergistic effects of octahedral $\mathrm{TiO}_{2}-\mathrm{MIL}-101(\mathrm{Cr})$ with two heterojunctions for enhancing visible-light photocatalytic degradation of liquid tetracycline and gaseous toluene. J. Colloid. Interface. Sci. 2020, 579, 37-49. [CrossRef] [PubMed]

6. Zhu, X.; Zhu, R.; Pei, L.; Liu, H.; Xu, L.; Wang, J.; Feng, W.; Jiao, Y.; Zhang, W.M. Fabrication, characterization, and photocatalytic activity of anatase/rutile/ $\mathrm{SnO}_{2}$ nanocomposites. J. Mater. Sci. Mater. Electron. 2019, 24, 21210-21218. [CrossRef]

7. Fouzia, A.; Rabah, B. The influence of doping lead and annealing temperature on grown of nanostructures of $\mathrm{TiO}_{2}$ thin films prepared by a sol-gel method. Mater. Sci. Eng. B 2021, 265, 114982. [CrossRef]

8. Ouerghi, O.; Geesi, M.H.; Ibnouf, E.O.; Ansari, M.J.; Alam, P.; Elsanousi, A.; Kaiba, A.; Riadi, Y. Sol-gel synthesized rutile $\mathrm{TiO}_{2}$ nanoparticles loaded with cardamom essential oil: Enhanced antibacterial activity. J. Drug. Deliv. Sci. Tec. 2021, 64, 102581. [CrossRef] 
9. Kumar, V.; Sharma, D.K. Fabrication of dimensional hydrophilic $\mathrm{TiO}_{2}$ nanostructured surfaces by hydrothermal method. Mater. Today 2021, 46, 2171-2174.

10. Zhang, M.; Wang, W.; Wu, C.; Wang, P.; Ru, H.Q. Rapid fabrication of $\mathrm{TiO}_{2}$ nanobelts with controllable crystalline structure by microwave-assisted hydrothermal method and their photocatalytic activity. Ceram. Int. 2019, 45, 22558-22563. [CrossRef]

11. Li, R.; Li, W.; Jin, C.; He, Q.; Wang, Y. Fabrication of ZIF-8@TiO 2 micron composite via hydrothermal method with enhanced absorption and photocatalytic activities in tetracycline degradation. J. Alloys Compd. 2020, 825, 154008. [CrossRef]

12. Cruz, M.A.; Sanchez-Martinez, D.; Torres-Martínez, L.M. $\mathrm{TiO}_{2}$ Nanorods grown by hydrothermal method and their photocatalytic activity for hydrogen production. Mater. Lett. 2018, 237, 310-313. [CrossRef]

13. Zhu, X.; Wen, G.; Liu, H.; Han, S.; Chen, S.; Kong, Q.; Feng, W. One-step hydrothermal synthesis and characterization of Cu-doped $\mathrm{TiO}_{2}$ nanoparticles/nanobucks/nanorods with enhanced photocatalytic performance under simulated solar light. J. Mater. Sci. Mater. Electron. 2019, 30, 13826-13834. [CrossRef]

14. Liu, N.; Chen, X.; Zhang, J.; Schwank, J.W. A review on $\mathrm{TiO}_{2}$-based nanotubes synthesized via hydrothermal method: Formation mechanism, structure modification, and photocatalytic applications. Catal. Today 2014, 225, 34-51. [CrossRef]

15. Najafi, M.; Kermanpur, A.; Rahimipour, M.R.; Najafizadeh, A. Effect of $\mathrm{TiO}_{2}$ morphology on structure of $\mathrm{TiO}_{2}$-graphene oxide nanocomposite synthesized via a one-step hydrothermal method. J. Alloys Compd. 2017, 722, 272-277. [CrossRef]

16. Esparza, P.; Hernández, T.; Borges, M.E.; Álvarez-Galván, M.C.; Ruiz-Morales, J.C.; Fierro, J.L.G. TiO 2 modifications by hydrothermal treatment and doping to improve its photocatalytic behaviour under visible light. Catal. Today 2013, 210, 135-141. [CrossRef]

17. Barrocas, B.; Monteiro, O.C.; Nunes, M.R.; Silvestre, A.J. Influence of Re and Ru doping on the structural, optical and photocatalytic properties of nanocrystalline $\mathrm{TiO}_{2}$. SN Appl. Sci. 2019, 1, 556. [CrossRef]

18. Nešić, J.; Manojlović, D.D.; Anđelković, I.; Dojčinović, B.P.; Vulić, P.J.; Krstić, J.; Roglić, G.M. Preparation, characterization and photocatalytic activity of lanthanum and vanadium co-doped mesoporous $\mathrm{TiO}_{2}$ for azo-dye degradation. J. Mol. Catal. A-Chem. 2013, 378, 67-75. [CrossRef]

19. Lee, D.-S.; Lee, S.-Y.; Rhee, K.; Park, S.-J. Effect of hydrothermal temperature on photocatalytic properties of $\mathrm{TiO}_{2}$ nanotubes. Curr. Appl. Phys. 2014, 14, 415-420. [CrossRef]

20. Mamaghani, A.H.; Haghighat, F.; Lee, C.S. Systematic variation of preparation time, temperature, and pressure in hydrothermal synthesis of macro-/mesoporous $\mathrm{TiO}_{2}$ for photocatalytic air treatment. J. Photochem. Photobiol. A 2019, 378, 156-170. [CrossRef]

21. HLi, H.; Shen, X.; Liu, Y.; Wang, L.; Lei, J.; Zhang, J.L. Facile phase control for hydrothermal synthesis of anatase-rutile TiO 2 with enhanced photocatalytic activity. J. Alloys Compd. 2015, 646, 380-386.

22. Nguyen-Phan, T.-D.; Pham, H.-D.; Cuong, T.V.; Kim, E.J.; Kim, S.; Shin, E.W. A simple hydrothermal preparation of TiO 2 nanomaterials using concentrated hydrochloric acid. J. Cryst. Growth 2009, 312, 79-85. [CrossRef]

23. Alves, A.K.; Berutti, F.A.; Bergmann, C.P. Visible and UV photocatalytic characterization of $\mathrm{Sn}^{-\mathrm{TiO}_{2}}$ electrospun fibers. Catal. Today 2013, 208, 7-10. [CrossRef]

24. Khatun, N.; Rajput, P.; Bhattacharya, D.; Jha, S.N.; Biring, S.; Sen, S. Anatase to rutile phase transition promoted by vanadium substitution in $\mathrm{TiO}_{2}$ : A structural, vibrational and optoelectronic study. Ceram. Int. 2017, 43, 14128-14134. [CrossRef]

25. Du, J.; Zhao, G.; Pang, H.; Qian, Y.; Liu, H.; Kang, D.J. A template method for synthesis of porous $\mathrm{Sn}_{\text {-doped }} \mathrm{TiO}_{2}$ monolith and its enhanced photocatalytic activity. Mater. Lett. 2013, 93, 419-422. [CrossRef]

26. Huang, W.C.; Ting, J.M. Novel nitrogen-doped anatase $\mathrm{TiO}_{2}$ mesoporous bead photocatalysts for enhanced visible light response. Ceram. Int. 2017, 43, 9992-9997. [CrossRef]

27. Mohamed, R.; Aazam, E. Effect of Sn loading on the photocatalytic aniline synthesis activity of $\mathrm{TiO}_{2}$ nanospheres. J. Alloys Compd. 2014, 595, 8-13. [CrossRef]

28. Adyani, S.M.; Ghorbani, M. A comparative study of physicochemical and photocatalytic properties of visible light responsive Fe, Gd and P single and tri-doped $\mathrm{TiO}_{2}$ nanomaterials. J. Rare Earths 2018, 36, 72-85. [CrossRef]

29. Sood, S.; Umar, A.; Mehta, S.K.; Kansal, S.K. Highly effective Fe-doped $\mathrm{TiO}_{2}$ nanoparticles photocatalysts for visible-light driven photocatalytic degradation of toxic organic compounds. J. Colloid Interface Sci. 2015, 450, 213-223. [CrossRef] [PubMed]

30. Liu, J.; Han, L.; An, N.; Xing, L.; Ma, H.; Cheng, L.; Yang, J.; Zhang, Q. Enhanced visible-light photocatalytic activity of carbonatedoped anatase $\mathrm{TiO}_{2}$ based on the electron-withdrawing bidentate carboxylate linkage. Appl. Catal. B: Environ. 2017, $202,642-652$. [CrossRef]

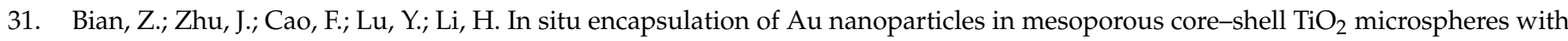
enhanced activity and durability. Chem. Commun. 2009, 25, 3789. [CrossRef]

32. Jing, L.Q.; Sun, X.J.; Xin, B.F.; Wang, B.Q.; Cai, W.M.; Fu, H.G. The preparation and characterization of La doped $\mathrm{TiO}_{2}$ nanoparticles and their photocatalytic activity. J. Solid State Chem. 2004, 177, 3375-3382.

33. Golubović, A.; Šćepanović, M.; Kremenovic, A.; Aškrabić, S.; Berec, V.; Dohčević-Mitrović, Z.; Popović, Z.V. Raman study of the variation in anatase structure of $\mathrm{TiO}_{2}$ nanopowders due to the changes of sol-gel synthesis conditions. J. Sol.-Gel Sci. Technol. 2009, 49, 311-319. [CrossRef]

34. Aghamalyan, N.R.; Gambaryan, I.A.; Goulanian, E.K.; Hovsepyan, R.K.; Kostanyan, R.B.; Petrosyan, S.I.; Vardanyan, E.S.; Zerrouk, A.F. Influence of thermal annealing on optical and electrical properties of ZnO films prepared by electron beam evaporation. Semicond. Sci. Technol. 2003, 18, 525-529. [CrossRef] 
35. Ali, Z.; Shah, A.; Ali, Z.; Mahmood, A. Influence of Cu modified surface states by sol gel Technique on Photocatalytic Activity of Titanium dioxide. Mater. Chem. Phys. 2020, 249, 123169. [CrossRef]

36. Chen, $\mathrm{H} . ; \mathrm{Xu}, \mathrm{Y}$. Cooperative effect between cation and anion of copper phosphate on the photocatalytic activity of $\mathrm{TiO}_{2}$ for phenol degradation in aqueous suspension. J. Phys. Chem. C 2012, 116, 24582-24589. [CrossRef]

37. Fan, X.; Wan, J.; Liu, E.; Sun, L.; Hu, Y.; Li, H.; Hu, X.Y.; Fan, J. High-efficiency photoelectrocatalytic hydrogen generation enabled by Ag deposited and Ce doped $\mathrm{TiO}_{2}$ nanotube arrays. Ceram. Int. 2015, 41, 5107-5116. [CrossRef]

38. Lei, X.F.; Xue, X.X.; Yang, H. Preparation and characterization of Ag-doped $\mathrm{TiO}_{2}$ nanomaterials and their photocatalytic reduction of Cr(VI) under visible light. Appl. Surf. Sci. 2014, 321, 396-403. [CrossRef]

39. Khaidukov, N.M.; Makhov, V.N.; Zhang, Q.; Shi, R.; Liang, H.B. Extended broadband luminescence of dodecahedral multisite $\mathrm{Ce}^{3+}$ ions in garnets $\left\{\mathrm{Y}_{3}\right\}[\mathrm{MgA}](\mathrm{BAlSi}) \mathrm{O}_{12}(\mathrm{~A}=\mathrm{Sc}, \mathrm{Ga}, \mathrm{Al} ; \mathrm{B}=\mathrm{Ga}, \mathrm{Al})$. Dyes Pigm. 2017, 142, 524-529. [CrossRef]

40. Wang, S.; Song, Z.; Kong, Y.; Liu, Q.L. Relationship of Stokes shift with composition and structure in $\mathrm{Ce}^{3+} / \mathrm{Eu}^{2+}$-doped inorganic compounds. Chinese. J. Lumin. 2019, 212, 250-263. [CrossRef]

41. Zhang, Y.; Wang, T.; Zhou, M.; Wang, Y.; Zhang, Z.M. Hydrothermal preparation of Ag-TiO ${ }_{2}$ nanostructures with exposed $\{001\} /\{101\}$ facets for enhancing visible light photocatalytic activity. Ceram. Int. 2017, 43, 3118-3126. [CrossRef]

42. Shi, F.; Liu, J.-X.; Huang, X.; Yu, L.; Liu, S.-H.; Feng, X.; Wang, X.-K.; Shao, G.-L.; Hu, S.-C.; Yang, B.; et al. Hydrothermal synthesis of mesoporous $\mathrm{WO}_{3}-\mathrm{TiO}_{2}$ powders with enhanced photocatalytic activity. Adv. Powder Technol. 2015, 26, 1435-1441. [CrossRef]

43. Si, Y.J.; Liu, H.H.; Li, N.T.; Zhong, J.B.; Li, J.Z.; Ma, D.M. SDBS-assisted hydrothermal treatment of $\mathrm{TiO}_{2}$ with improved photocatalytic activity. Mater. Lett. 2018, 212, 147-150. [CrossRef]

44. Tang, H.; Zhang, D.; Tang, G.; Ji, X.; Li, W.; Li, C.; Yang, X. Hydrothermal synthesis and visible-light photocatalytic activity of $\alpha-\mathrm{Fe}_{2} \mathrm{O}_{3} / \mathrm{TiO}_{2}$ composite hollow microspheres. Ceram. Int. 2013, 39, 8633-8640. [CrossRef]

45. Huang, J.; Ding, L.; Xi, Y.; Shi, L.; Su, G.; Gao, R.; Wang, W.; Dong, B.; Cao, L.X. Efficient silver modification of TiO 2 nanotubes with enhanced photocatalytic activity. Solid State Sci. 2018, 80, 116-122. [CrossRef]

46. Sun, Y.; Gao, Y.; Zeng, J.; Guo, J.; Wang, H. Enhancing visible-light photocatalytic activity of Ag-TiO 2 nanowire composites by one-step hydrothermal process. Mater. Lett. 2020, 279, 128506. [CrossRef]

47. Sun, Y.; Gao, Y.; Zhao, B.; Xu, S.; Luo, C.; Zhao, Q. One-step hydrothermal preparation and characterization of $\mathrm{ZnO}^{-T i O}{ }_{2}$ nanocomposites for photocatalytic activity. Mater. Res. Express 2020, 7, 085010. [CrossRef]

48. Qin, J.; Wang, J.; Yang, J.; Hu, Y.; Fu, M.; Ye, D. Metal organic framework derivative- $\mathrm{TiO}_{2}$ composite as efficient and durable photocatalyst for the degradation of toluene. Appl. Catal. B: Environ. 2020, 267, 118667. [CrossRef]

49. Li, J.; Wan, Y.; Li, Y.; Yao, G.; Lai, B. Surface Fe(III)/Fe(II) cycle promoted the degradation of atrazine by peroxymonosulfate activation in the presence of hydroxylamine. Appl. Catal. B: Environ. 2019, 256, 117782. [CrossRef] 